\title{
Czynności notarialne online - podstawy de lege lata i uwagi de lege ferenda
}

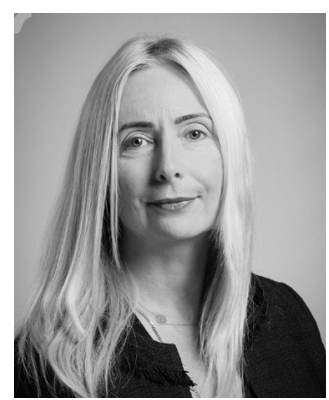

\section{Ewa Rott-Pietrzyk \\ Profesor nauk prawnych w Instytucie Nauk Prawnych na Wydziale Prawa i Admini- stracji Uniwersytetu Śląskiego $w$ Katowicach. \\ $\triangle$ ewa.rott-pietrzyk@us.edu.pl https://orcid.org/0000-0002- 7057-9383}

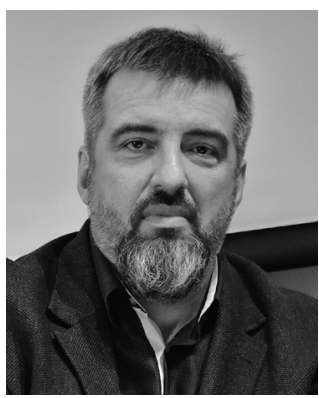

\section{Fryderyk Zoll}

Profesor nauk prawnych

w Katedrze Prawa Cywilnego Uniwersytetu Jagiellońskiego oraz $w$ European Legal Studies Institute Uniwersytetu Osnabrück, doktor honoris causa Narodowego Uniwersytetu Ekonomicznego w Tarnopolu. $\triangle$ fryderyk.zoll@uj.edu.pl https://orcid.org/oooo-0oo17263-2670
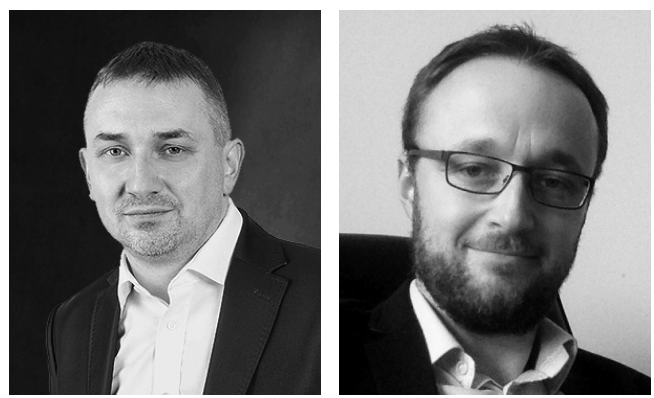

\section{Dariusz Szostek}

Doktor habilitowany nauk prawnych, profesor Uniwersytetu Opolskiego, kierownik Centrum Problemów Prawnych Techniki i Nowych Technologii UO.

$\square$ dariusz.szostek@ szostek-bar.pl https://orcid.org/0000-0002$8924-6968$

\section{Mateusz Grochowski}

Doktor nauk prawnych, LL.M. Yale, adiunkt $w$ Instytucie Nauk Prawnych PAN, Fellow $w$ Information Society Project (Yale Law School).

$\triangle$ mateusz.grochowski@ aya.yale.edu https://orcid.org/0000-00015013-4830

\section{The Notary Legal Acts - de lege lata and de lege ferenda}

\footnotetext{
The text attempts to conceptualize the possible reform of the procedure of making notarial deeds in Poland. It examines the feasibility of drafting and signing these deeds in the course of online communication between parties. The analysis builds on the significant constraints for the classic notarial procedure (based on paper documents and on the physical presence of a notary and parties) that were triggered by the COVID-19 pandemic. Its aim reaches, however, further beyond the present-day realities and seeks possible ways to generally modernize provisions on notarial deeds and to adjust them to the growing proliferation of online communication in the society. The text ascertains that the existing structure of provisions on notarial deeds already allows for making notarial deeds online, without profound legislative changes. It can be achieved predominantly by altering the attitude towards interpretation of these rules, especially through a more profound insight into the function
} 
of these provisions and the interrelation between their rationale and the features of the online communication. In the latter regards, the text makes an in-depth scrutiny of possible guarantees for communicational efficacy and for authenticity of notarial deeds that are provided by the advanced methods of transmitting and storing data online.

Słowa kluczowe: elektroniczny akt notarialny, notariat, nowe technologie, forma czynności prawnych, COVID-19 Key words: notarial deed, new technologies, notarisation, notarial legal acts, online legal acts https://doi.org/10.32082/fp.v0i4(60).369

\section{Wprowadzenie}

Pandemia COVID-19 pociągnęła za sobą - i pociąga nadal - diametralne zmiany w niemal wszystkich sferach życia społecznego i gospodarczego. Dotyczą one także obrotu notarialnego, który zgodnie z tradycyjnym ujęciem realizowany jest przede wszystkim przy jednoczesnej obecności notariusza i uczestników czynności notarialnych ${ }^{1}$. W tych warunkach na uwagę

1 Dotąd opublikowano w zakresie wpływu COVID-19 na praktykę notarialną trzy zasadnicze dokumenty na oficjalnej stronie KRN (https://www.krn.org.pl/1193/Aktualnosci): 1) Stanowisko Krajowej Rady Notarialnej z dnia 24 marca 2020 r. w związku z wydaniem 24 marca 2020 r. rozporządzenia Ministra Zdrowia zmieniającego rozporządzenie w sprawie ogłoszenia na obszarze Rzeczypospolitej Polskiej stanu epidemii oraz licznymi zapytaniami notariuszy kierowanymi do organów samorządu notarialnego, dotyczącymi zasad funkcjonowania kancelarii notarialnych;

2) Stanowisko rzecznika prasowego Krajowej Rady Notarialnej z 28 marca 2019 r. w sprawie sposobu funkcjonowania kancelarii notarialnych po ogłoszeniu rozporządzenia Ministra Zdrowia z dnia 24 marca 2020 r. zmieniającego rozporządzenie w sprawie ogłoszenia na obszarze Rzeczypospolitej Polskiej stanu epidemii przygotowane w odpowiedzi na zapytanie dziennika „Rzeczpospolita”; 3) Stanowisko KRN z 1 kwietnia 2020 r. w związku z wydaniem w dniu 31 marca 2020 roku rozporządzenia Rady Ministrów w sprawie ustanowienia określonych ograniczeń, nakazów i zakazów w związku z wystąpieniem stanu epidemii. Ze stanowiska KRN, odnoszącego się do rozporządzenia Rady Ministrów z dnia 31 marca 2020 r. w sprawie ustanowienia określonych ograniczeń, nakazów i zakazów w związku z wystąpieniem stanu epidemii (Dz.U. 2020, poz. 566), wynika między innymi, że „działalność kancelarii notarialnej jako jednostki organizacyjnej wykonującej zadania o charakterze publicznym objęta jest dyspozycją przepisu $\$ 13$ ust. 2 rozporządzenia, a zatem regulacja ta daje między innymi notariuszom możliwość ograniczenia funkcjono- tym bardziej zasługuje podnoszone już od pewnego czasu $^{2}$ pytanie, czy obecna wykładnia i praktyka stosowania przepisów o czynnościach notarialnych - w szczególności odnosząca się do sposobu sporządzania aktów notarialnych - nie wymaga zmiany i unowocześnienia. $Z$ bieżącej perspektywy zmiana ta

wania kancelarii do sytuacji wskazanych wyraźnie w $\$ 13$ ust. 1 punkty 1 i 2 rozporządzenia w okresie, o którym mowa w $\$ 2$ ust. 1 rozporządzenia (od dnia 31 marca $2020 \mathrm{r}$. do odwołania)". Ponadto w odniesieniu do $\$ 13$ ust. 2 tego rozporządzenia przyjęto, że „w przypadku kancelarii notarialnej decyzję o rodzaju i formie ograniczeń w jej funkcjonowaniu podejmuje notariusz". Problem ten obrazują także informacje prasowe: E. Wasińska, Sytuacja notariuszy w obliczu zagrożenia epidemia koronawirusa (17.03.2020), https://www.lex.pl/sytuacja-prawna-notariuszy-w-obliczu-zagrozenia-epidemia-koronawirusa,6181; P. Rojek-Socha, J. Ojczyk, Koronawirus zatapia notariuszy, kołem ratunkowym - akty online (3.04.2020), https://www.prawo.pl/ prawnicy-sady/elektroniczny-akt-notarialny-rekomendacje-jak-wprowadzic-w,499237.html; P. Rojek-Socha, Kancelarie notarialne zamykają się z powodu koronawirusa (28.04.2020), https://www.prawo.pl/prawnicy-sady/kancelarie-notarialne-zamykaja-sie-z-powodu-koronawirusa-dane,499846.html; D. Mikulska, Czy w obecnej sytuacji możliwe jest doprowadzenie do sprzedaży nieruchomości? (25.03.2020), https://www. nieruchomosci-online.pl/porady/epidemia-koronawirusa-czy-mozliwa-jest-sprzedaz-nieruchomosci-11545.html.

2 A. Oleszko, Akty notarialne. Komentarz (art. 91-95 Prawa o notariacie), Warszawa 2012, s. 168; J. Przetocki, Wykorzystanie środków przekazu elektronicznego, między innymi e-podpisu w praktyce notarialnej, „Rejent” 2006, nr 5, s. 165 180; M. Lorenc, Elektroniczna forma notarialna, rozwiazania przyjęte w prawie europejskim - model francuski, „Nowy Przegląd Notarialny” 2008, nr 1, s. 16-24; K. Rymanowska-Mrugała, Akt notarialny jako szczególna forma dokumentu urzędowego, „Folia Iuridica Universitatis Wratislaviensis” 2016, t. 5, nr 1, s. 219-238. 
ułatwiłaby zapobieżenie skutkom pandemii COVID19 zarówno w sferze gospodarczej, jak i w stosunkach społecznych na różnych płaszczyznach ${ }^{3}$. Miałaby ona jednak także znacznie szersze skutki, pozwalając na trwałą modernizację obrotu notarialnego i na dostosowanie go - wzorem innych krajów - do nowych możliwości i potrzeb, jakie stwarza rozwój technologiczny. ści prawnych ${ }^{4}$ i czynił zadość wszelkim gwarancjom, jakie są związane z tradycyjnym aktem notarialnym.

Dalsze uwagi stanowią próbę bliższego spojrzenia na problem dopuszczalności dokonywania czynności notarialnych - zwłaszcza sporządzania aktów notarialnych - z wykorzystaniem elektronicznych środków porozumiewania się na odległość. Zamiarem autorów jest także zarysowanie ogólnych kierunków rozwią-

\section{Sytuacja spowodowana przez COVID-19 skłania} do uelastycznienia praktyki sporządzania aktów notarialnych przez wykorzystanie narzędzi, które udostępniają nowe technologie.

Zdaniem autorów artykułu inne, bardziej nowoczesne podejście do sporządzenia formy aktu notarialnego $\mathrm{z}$ wykorzystaniem nowych technologii jest możliwe w aktualnym stanie prawnym w drodze wykładni obowiązujących przepisów (z zastrzeżeniem niewielkich korekt legislacyjnych, dotyczących bardziej zagadnień technicznych). Sytuacja spowodowana przez COVID-19 szczególnie jednak skłania do uelastycznienia praktyki sporządzania aktów notarialnych przez wykorzystanie narzędzi, które udostępniają nowe technologie. Podstawowe założenie autorów sprowadza się to tego, aby sporządzony w ten sposób akt realizował wszystkie dotychczasowe funkcje tej formy czynno-

3 W ustawie $\mathrm{z}$ dnia 31 marca 2020 r. o zmianie ustawy o szczególnych rozwiązaniach związanych z zapobieganiem, przeciwdziałaniem i zwalczaniem COVID-19, innych chorób zakaźnych oraz wywołanych nimi sytuacji kryzysowych oraz niektórych innych ustaw (Dz.U. z 2020 r., poz. 568), nie wspomina się w ogóle o narzędziach dotyczących zapewnienia sprawnego i nieprzerwanego działania kancelarii notarialnych; podobnie w ustawie o zmianie niektórych ustaw w zakresie działań osłonowych w związku z rozprzestrzenianiem się wirusa SARS-CoV-2, uchwalonej 30.04.2020 r., druk sejmowy 344-A, http://orka.sejm.gov. pl/opinie9.nsf/nazwa/344_u/\$file/344_u.pdf. zania podstawowych problemów, jakie współcześnie mogą stać na przeszkodzie pełniejszej digitalizacji obrotu notarialnego. Z konieczności w opracowaniu tym nie zostały poruszone wszystkie (zwłaszcza bardziej techniczne) zagadnienia związane z poszerzeniem możliwości dokonywania czynności notarialnych online. Autorzy mają jednak nadzieję, że ich rozważania pozwolą na bardziej precyzyjne sformułowanie zakresu przedmiotowego problemu aktów notarialnych sporządzanych online i docenienie potencjału, który tkwi w obecnie obowiązujących przepisach prawa polskiego. W dalszej perspektywie podjęcie tego zagadnienia może - na co liczą autorzy - otworzyć także pole do szerszej dyskusji de lege ferenda odnoszącej się w sposób systemowy, a nie punktowy, do dokonywania aktów notarialnych z wykorzystaniem nowych technologii.

\section{Diagnoza dotyczaca zakresu potrzeby wprowadzenia aktów notarialnych dokonywanych online}

W obecnych realiach szczególnie istotne stało się otwarcie możliwości składania oświadczeń woli w for-

4 Odnośnie do funkcji i celów wymogów formalnych zob. bliżej M. Grochowski, Skutki braku zachowania formy szczególnej, Warszawa 2017, s. 36 i n. 
mie notarialnej z wykorzystaniem nowych technologii (w szczególności postaci elektronicznej aktu notarialnego), w celu ograniczenia fizycznego kontaktu uczestników obrotu ze sobą i notariuszem. Nie jest to pogląd odosobniony w Europie. Podobne stanowisko przyjęto
Po pierwsze bowiem dostępne narzędzia technologiczne na to dzisiaj pozwalają. Po drugie, w prawie polskim już w 2015 roku wprowadzono tzw. postępowanie odmiejscowione ${ }^{8}$, w ramach którego rozprawa sądowa może być przeprowadzana w całości online.

\section{W obecnych realiach szczególnie istotne} stało się otwarcie możliwości składania oświadczeń woli w formie notarialnej z wykorzystaniem nowych technologii.

w rekomendacjach Europejskiego Instytutu Prawa ${ }^{5}$ w związku z pandemią COVID-19 (ELI Principles for the COVID-19 Crisis) ${ }^{6}$. Zgodnie z zasadą 10(1) państwa powinny zapewnić możliwość zawierania umów i podejmowania innych działań prawnych - w tym dokonywania czynności notarialnych - na odległość ${ }^{7}$. Potwierdza to konieczność ukształtowania przepisów o formie notarialnej w sposób, który pozwoliłby na dokonywanie ich bez fizycznej obecności zaangażowanych osób - co pociąga za sobą konieczność określonego stopnia ich digitalizacji.

COVID-19 należy jednak postrzegać wyłącznie jako pretekst dla rozważań objętych publikacją. Uważamy bowiem, że proponowane rozwiązania nie powinny dotyczyć wyłącznie czasu pandemii. Konieczność osobistego, fizycznego stawienia się u notariusza - choć optymalna w zakresie spełnienia gwarancji i funkcji czynności notarialnych - mogłaby na stałe być realizowana $\mathrm{z}$ wykorzystaniem systemu teleinformatycznego.

5 European Law Institute (ELI). Oficjalna strona Instytutu: https://www.europeanlawinstitute.eu/.

6 Zasady dostępne są na stronie: https://www.europeanlawinstitute.eu/fileadmin/user_upload/p_eli/Publications/ ELI_Principles_for_the_COVID-19_Crisis.pdf.

7 Orginalny tekst zasady 10(1): „States should ensure that contracts can be concluded, management decisions can be made, and all other legal steps can be taken at a distance, including notarisation and other participation by notaries".
Wprowadzono także możliwość przeprowadzenie dowodu, w tym przesłuchiwania świadka na odległość 9 . Począwszy od 21 kwietnia 2020 r. w polskich sądach powszechnych przeprowadzane są rozprawy w pełni online, w ramach których nie tylko strony

8 Por. art. 151 k.p.c., zgodnie z którym „przewodniczący może zarządzić przeprowadzenie posiedzenia jawnego przy użyciu urządzeń technicznych umożliwiających jego przeprowadzenie na odległość. W takim przypadku uczestnicy postępowania mogą brać udział w posiedzeniu sądowym, gdy przebywają w budynku innego sądu, i dokonywać tam czynności procesowych, a przebieg czynności procesowych transmituje się z sali sądowej sądu prowadzącego postępowanie do miejsca pobytu uczestników postępowania oraz z miejsca pobytu uczestników postępowania do sali sądowej sądu prowadzącego postępowanie"; szerzej. R. Markiewicz, Komentarz do art. 151 (w:) Kodeks postępowania cywilnego, t. 1, Komentarz do art. 1-505 $5^{39}$, red. T. Szanciło, Warszawa 2019, s. 591.

9 Por. art. $235 \$ 2$ k.p.c., zgodnie z którym: ,Jeżeli charakter dowodu temu się nie sprzeciwia, sąd orzekający może postanowić, że jego przeprowadzenie nastąpi przy użyciu urządzeń technicznych umożliwiających dokonanie tej czynności na odległość”. Bliżej na ten temat A. Klich (w:) Informatyzacja postępowania cywilnego. Komentarz, red. J. Gołaczyński, D. Szostek, Warszawa 2016, s. 179 i n.; A. Łazarska, Komentarz (w:) Kodeks postępowania cywilnego, t. 1, Komentarz do art. $1-505^{39}$..., s. 907-908. Co istotne, przeprowadzenie dowodu na podstawie art. $235 \$ 2$ k.p.c. może być dokonane z każdego miejsca, nie tylko z budynku sądu. 
postępowania, ale także część składu sądzącego może funkcjonować zdalnie, poza budynkiem sądu. Podobne rozprawy uruchomiono w czasie COVID-19 w wielu państwach ${ }^{10}$. Należy przyjąć, że czynności te swoją wagą nie odbiegają wszak od czynności notarialnych. Po trzecie, należy uwzględnić na przyszłość rozwiązania tzw. Zielonego Ładu (European Green Deal), w przypadku gdy udzielenie pełnomocnictwa również wymaga dokonania czynności notarialnej (art. 99 $\$ 1$ k.c.). Sytuacja ta w oczywisty sposób może ograniczać dostęp także do innych instrumentów prawnych, np. czynności mortis causa: testamentu (art. 950 k.c.) oraz innych czynności z zakresu prawa spadkowego, jak stwierdzenie nabycia spadku (art. $1025 \$ 1$ k.c.),

\section{Warto rozważyć - w szczególności z uwagi na} potrzeby obrotu - rozwiązania umożliwiające dokonywanie czynności prawnych w formie aktu notarialnego w sposób bezpieczny i efektywny bez konieczności kontaktów bezpośrednich między uczestnikami obrotu.

ograniczające emisję $\mathrm{CO}_{2}$, a przez to promujące działania na odległość, bez niepotrzebnego transportu ${ }^{11}$.

Zagrożenie związane z COVID-19 z jednoczesnym administracyjnym utrzymywaniem ograniczeń życia społecznego i gospodarczego w kolejnych miesiącach spowoduje w większej skali spowolnienie (jeśli nie zatrzymanie) obrotu ${ }^{12}$ w sektorach, które w przeważającej mierze opierają się na czynnościach notarialnych. Dotyczy to zwłaszcza obrotu nieruchomościami (art. 158 k.c.) wraz z usługami pośrednictwa,

10 Covid-19 pandemic. Impact of COVID-19 on Court Operations $\$$ Litigation Practice, ed. J. Galway, U. Hoffmann-Nowotny, International Bar Associattion, https://www.lalive.law/ wp-content/uploads/2020/05/2020-SGI-IBA_Impact_of_ COVID-19_on_court_operations_and_litigation_practice. pdf (dostęp 16.06. 2020)

11 Bliżej na ten temat na oficjalnej stronie, https://ec.europa.eu/ info/strategy/priorities-2019-2024/european-green-deal_pl.

12 Z danych KRN przekazanych portalowi prawo.pl, https:// www.prawo.pl/prawnicy-sady/kancelarie-notarialne-zamykaja-sie-z-powodu-koronawirusa-dane,499846.html (dostęp 29.04.2020) z 3600 kancelarii notarialnych - 367 jest zamkniętych, a kolejnych 769 ograniczyło swoje działanie. odrzucenie spadku (art. 1015 k.c.) oraz dział spadku (art. $1037 \$ 2$ k.c. $)^{13}$. Problem ten może okazać się szczególnie istotny dla osób dysponujących ograniczoną wiedzą o sposobach dokonania omawianych czynności bez udziału notariusza (np. przez wybór alternatywnej formy testamentu), ograniczonymi zasobami finansowymi lub pozostających pod presją czasu. W konsekwencji sytuacja ta może prowadzić do pogłębiania słabości niektórych uczestników obrotu i ich wtórnej segregacji. Na marginesie można dodać, że wiele osób (w szczególności starszych) może w najbliższym czasie, z uwagi na zagrożenie, unikać sporządzania testamentów w formie aktu notarialnego i poszukiwać innych rozwiązań ${ }^{14}$. Należy jednak mieć świadomość, że w grupie osób starszych problem może stanowić

13 Por. uwagi: K. Osajda, Prawo spadkowe (w) przyszłości. Perspektywy rozwoju prawa spadkowego, „Monitor Prawniczy” 2019, nr 2, s. 72, 73, a także komentarz K. Dobrowolskiego zamieszczony w opracowaniu D. Mikulskiej, Czy w obecnej sytuacji..., odnoszący się np. do odrzucenia spadku.

$14 \mathrm{~W}$ tym zakresie alternatywa może wynikać $\mathrm{z}$ analizy i wniosków K. Osajdy, Prawo spadkowe..., s. 73, 74. 
już sama perspektywa dokonania aktu notarialnego online (zwłaszcza w związku z technicznym lub mentalnym wykluczeniem cyfrowym). W konsekwencji do rozważenia pozostaje stworzenie dla takich osób dodatkowej pomocy w skorzystaniu z elektronicznego trybu dokonania czynności prawnej (np. przez zapewnienie im poszerzonej asysty notariusza).

Warto zatem w tym kontekście rozważyć - w szczególności z uwagi na potrzeby obrotu - rozwiązania umożliwiające dokonywanie czynności prawnych w formie aktu notarialnego w sposób bezpieczny i efektywny bez konieczności kontaktów bezpośrednich między uczestnikami obrotu (przede wszystkim obrotu handlowego, ale także powszechnego i konsumenckiego ${ }^{15}$ ).

Dotychczas wielokrotnie podnoszone były (i są nadal) argumenty na rzecz tradycyjnego modelu dokonywania czynności notarialnych (w szczególności sporządzenia aktu notarialnego), wśród których należy wyróżnić trzy zasadnicze kwestie:

Po pierwsze, tradycyjne ujęcie aktu notarialnego i uczynienie zadość wszelkim wymogom procedury związanym z tą formą wymagają osobistego stawiennictwa stron lub składającego oświadczenie woli przed notariuszem $^{16}$.

Po drugie, składanie skutecznych oświadczeń woli $\mathrm{w}$ formie aktu notarialnego online nie jest obecnie przyjęte w praktyce (w związku z wątpliwościami dotyczącymi dopuszczalności wprowadzenia praktyki sporządzania aktu notarialnego na odległość ${ }^{17}$.

Po trzecie, w praktyce występuje powszechnie przekonanie, że obowiązujące przepisy odnoszą się expressis verbis wyłącznie do tradycyjnie ujętej formy aktu

15 Por. także uwagi w pkt 7. niniejszego opracowania.

16 Por. bliżej E. Drozd, Z. Kuniewicz (w:) Prawo cywilne-część ogólna, red. Z. Radwański, A. Olejniczak, „System Prawa Prywatnego", t. 2, wyd. 3, Warszawa 2019, s. 228, 229.

17 Por. Stanowisko rzecznika prasowego KRN z dnia 28 marca 2020 r. w sprawie sposobu funkcjonowania kancelarii notarialnych po ogłoszeniu rozporządzenia Ministra Zdrowia z dnia 24 marca 2020 r. zmieniającego rozporządzenie w sprawie ogłoszenia na obszarze Rzeczypospolitej Polskiej stanu epidemii przygotowane w odpowiedzi na zapytanie dziennika „Rzeczpospolita”, dostępne na stronie KRN, https://www.krn.org.pl/1193/Aktualnosci; zob. także K. Rymanowska-Mrugała, Akt notarialny..., s. 235 oraz passim. notarialnego i związanej z nim procedury zakładającej obecność (fizyczną) wszystkich uczestników przed notariuszem, niezbędną do dokonania danego aktu notarialnego (ewentualnie składanie oświadczeń woli przez pełnomocników) ${ }^{18}$. Przyjmowana jest tu zasada unitas actus, wyrażająca się m.in. w tym, że akt notarialny powinien być odczytany w obecności wszystkich osób wymienionych w komparycji (pierwszej części aktu notarialnego $)^{19}$.

$\mathrm{W}$ naszej ocenie argumenty te nie przemawiają stanowczo za tym, aby - zadowalając się stanem aktualnie przyjmowanym w praktyce notarialnej - nie czynić kroków umożliwiających otwarcie notariatu na dokonywanie czynności notarialnych przy zastosowaniu nowych technologii. Uważamy, że warto rozpocząć pierwszy etap na drodze zmierzającej do unowocześnienia praktyki notarialnej, sprowadzający się do przedstawienia argumentów na rzecz zmiany tej praktyki i dyskusji nad nimi. Etap ten - w kontekście COVID-19 - nie powinien trwać jednak zbyt długo, z uwagi na koszty społeczne obecnej sytuacji związane z ograniczeniem bądź brakiem powszechnego dostępu do czynności notarialnych. Przedstawiając nasze stanowisko w tym zakresie, stawiamy sobie za cel zainicjowanie takiej dyskusji; innymi słowy - naszym celem jest zainicjowanie pierwszego kroku na drodze zmiany praktyki notarialnej w kierunku otwarcia jej na nowe technologie.

\section{Metodologia wykładni przepisów dotyczacych formy aktu notarialnego}

Niejednokrotnie w historii prawa, w tym także prawa prywatnego, gwałtowne zmiany historyczne były impulsem do ponownego przemyślenia znaczenia norm prawnych. Takie innowacyjne podejście do istniejących konstrukcji prawnych nie budziło na przykład zdziwienia wkrótce po pierwszej wojnie światowej, gdy w praktyce obrotu pojawiło się pytanie, w jaki sposób prawo prywatne powinno zareagować na złożoną zastaną sytuację ${ }^{20}$. Podobnie jest w przypadku

18 Por. także stanowisko, o którym mowa w poprzedzającym przypisie.

19 Bliżej E. Drozd, Z problematyki zawarcia umowy $w$ formie aktu notarialnego, „Rejent” 1996, nr 4-5, s. 15, 16.

20 Odnośnie do roli prawa cywilnego w zmienionych okolicznościach wywołanych pierwszą wojną światową zob. 
wystąpienia zmian tak gwałtownych jak te, które mają obecnie miejsce, i które w tak radykalny sposób wpływają na rzeczywistość. Tego rodzaju stan zmieniających się gwałtownie okoliczności, których ustawodawca nie wziął pod uwagę w chwili tworzenia prawa, wymaga nadzwyczajnej, w której utrzymywanie normalnych kontaktów międzyludzkich jest skrajnie ograniczone. Jak wynika z dalszych rozważań, rozstrzygnięcie tego dylematu nie ogranicza się wyłącznie do kontekstu pandemii COVID-19. Z ustaleń autorów tego opra-

\section{Niejednokrotnie w historii prawa gwałtowne} zmiany historyczne były impulsem do ponownego przemyślenia znaczenia norm prawnych.

dzisiaj udzielenia odpowiedzi na pytanie, czy w ramach obowiązującego porządku prawnego jest możliwe odpowiednie dostosowanie istniejących instytucji prawnych do nowych warunków życia społecznego ${ }^{21}$. Jednym z obszarów, w ramach którego pytania te pojawiają się z pełną ostrością, jest zagadnienie dochowania wymogów „innych form szczególnych” zwłaszcza zaś tych, które wymagają uczestnictwa notariusza. Jeśli chodzi o formę aktu notarialnego, do tej pory przepisy dotyczące tej formy były interpretowane restryktywnie, przez co w praktyce notarialnej nie dopuszczano możliwości sporządzenia czynności notarialnej z zastosowaniem środków komunikacji na odległość ${ }^{22}$. W obecnej sytuacji, wywołanej przez pandemię COVID-19, pojawia się pytanie, czy można interpretować przepisy o formie czynności notarialnych tak, aby ich dokonanie na odległość uznać za dopuszczalne. W tym kontekście do zasadniczych należy pytanie, czy w przypadku czynności notarialnych istnieje możliwość bardziej liberalnej wykładni przepisów tylko ze względu na obecny stan zagrożenia wypełniający - z punktu widzenia prawa materialnego przesłanki konstytucyjnych stanów nadzwyczajnych. Istotne jest przy tym, czy tego rodzaju wykładnia miałaby zostać ograniczona wyłącznie do sytuacji

B. Rüthers, Die Unbegrenzte Auslegung, Tübingen 2012, s. $37,42,69,216$.

21 Zob. F. Bydlinski, Juristische Methodenlehre und Rechtsbegriff, Wien 1991, s. 128.

22 Por. także A. Oleszko, Akty notarialne..., s. 168. cowania wynika bowiem, że już obecnie obowiązujące przepisy dostarczają wystarczająco mocnych argumentów do przyjęcia, że dokonywanie czynności notarialnych online jest możliwe. Dopuszczalność dokonywania czynności notarialnych na odległość przy odpowiednim ich procedowaniu pozwala na ochronę tych samych interesów i w takim samym stopniu, jak to ma miejsce w przypadku czynności notarialnej dokonywanej w sposób tradycyjny.

Postawione na wstępie pytanie jednak pozostaje: czy można sobie wyobrazić szczególny reżim przepisów regulujących formę wyprowadzony jedynie w drodze wykładni? Takiego rozwiązania nie można w sposób stanowczy wykluczyć. Wykładnia norm prawnych odnosi się zawsze do rzeczywistości zarówno przestrzennej, czasowej, jak i społecznej, w której jest dokonywana. Oznacza to, że dane normy muszą spełnić swoje zadania i z tego powodu, ujmując to zagadnienie całkowicie abstrakcyjnie, można sobie wyobrazić wykładnię usprawiedliwiającą odejście od danej praktyki jedynie ze względu na wyjątkowe okoliczności. Jednakże, nie odrzucając takiej możliwości, należy podejść do niej z dużym dystansem, ponieważ przy niejasno określonych przesłankach „wyjątkowości sytuacji” mogłaby rodzić się obawa, czy dana czynność została skutecznie dokonana. W konsekwencji mogłoby to prowadzić do wątpliwości co do ważności czynności prawnych, której ocena z perspektywy czasu byłaby coraz trudniejsza.

W przypadku tu omawianym obowiązujące przepisy dostarczały wystarczającej podstawy już wcześniej, 
niezależnie od obecnej sytuacji związanej z COVID-19. Pokazuje ona jedynie naglącą potrzebę odczytania przepisów w nowy sposób, uwzględniający możliwości wynikające z nowych technologii. Co więcej, można rzec, że nie wymaga to nawet stosowania wykładni funkcjonalnej obowiązujących przepisów dotyczących czynności notarialnych, w tym w szczególności aktu notarialnego, są one bowiem wystarczająco pojemne. wynikają już z samej wykładni językowej. Każdy przypadek $^{23}$ zastrzeżenia formy szczególnej dla złożenia oświadczenia woli lub dla dokonania innej czynności służy zawsze określonemu celowi - najczęściej uzyskaniu trwałego dowodu na fakt złożenia i treść danego oświadczenia (funkcja dowodowo-dokumentacyjna) ${ }^{24}$, często także stworzeniu dla jednej lub obu stron dodatkowej okazji do namysłu nad dokonywaną czynnoś-

\section{W sytuacji wywołanej przez pandemię COVID-19} pojawia się pytanie, czy można interpretować przepisy o formie czynności notarialnych tak, aby ich dokonanie na odległość uznać za dopuszczalne.

Dotychczas były jednak rozumiane zbyt wąsko (niepoprawnie), mimo że dostępna technologia i wiążące się z nią możliwości pozwalają na szersze rozumienie, bez konieczności stosowania redukcji teleologicznej, co w praktyce, nie nazywając tego tak, czyniono. Proponowany w tym opracowaniu kierunek wykładni odpowiada także funkcji i ratio legis stosowanych przepisów. Występuje tu zatem ze wszech miar pożądana zgodność wyników wykładni językowej i wykładni funkcjonalnej.

Z uwagi na tradycję innego rozumienia omawianych przepisów w dziedzinie, w której pewność prawa jest szczególnie doniosłą wartością, pożądana byłaby jedynie niewielka interwencja legislacyjna, ograniczona do zagadnień technicznych, pozwalających na wykorzystanie obowiązujących przepisów do dokonywania czynności notarialnych na odległość.

\section{Przepisy o dokumentach notarialnych} (konieczność wykładni funkcjonalnej, a raczej niezredukowanej teleologicznie wykładni językowej)

W systemie prawa przepisy o formie szczególnej ze swojej istoty powinny być odczytywane przez pryzmat pełnionej w obrocie funkcji. Przede wszystkim jednak należy w pełni wykorzystać te możliwości, które cią i do zrozumienia jej skutków prawnych (funkcja ostrzegawcza) ${ }^{25}$. W przypadku czynności notarialnych typową funkcją formy szczególnej (aktu notarialnego, formy pisemnej z podpisem notarialnie poświadczonym czy formy pisemnej z datą pewną) jest pewność i bezpieczeństwo obrotu, co zapewnia udział notariusza.

Notariusz dokonuje zarówno urzędowego poświadczenia określonego faktu (np. własnoręczności złożonego podpisu), jak również kontroli treści czynności pod względem jej zgodności z prawem. Dodatkowo może on udzielać stronom pouczeń co do sposobu sformułowania treści aktu oraz jego skutków prawnych $^{26}$. Z tych powodów forma czynności prawnej

23 Dotyczy to zarówno zastrzeżenia formy szczególnej w ustawie, jak i w drodze umownej (pactum de forma) - co odnosi się także do umownego zastrzegania formy aktu notarialnego.

24 Bliżej m.in. P. Mankowski, Formzwecke, „JuristenZeitung” 2010, nr 13, s. 662-668; K. Górska, Zachowanie zwykłej formy pisemnej czynności prawnych, Warszawa 2007, s. 16-20; M. Grochowski, Skutki braku..., s. 36-38.

25 M. Grochowski, Skutki braku..., s. 38; J. Górecki, Forma umów obligacyjnych i rzeczowych $w$ prawie prywatnym międzynarodowym, Katowice 2007, s. 26 i n.

26 Por. w szczególności art. 80 pr. not. 
związana z działalnością notariusza (np. forma aktu notarialnego) jest zastrzegana jako przesłanka ważności ${ }^{27}$ czynności prawnych o szczególnej doniosłości dla obrotu - m.in. umów i czynności prawnych dotyczących powołania do życia i działania spółek prawa handlowego (np. na podstawie art. 106 k.s.h.) oraz czynności prawnych przenoszących własność nieruchomości (art. 158 k.c.) ${ }^{28}$.
W nadzwyczajnych okolicznościach może jednak dochodzić do sytuacji, kiedy należy odwołać się wprost do funkcji danego wymogu formy szczególnej i stwierdzić, czy w danych warunkach nadal ma on znaczenie dla stron, czy też staje się dla nich niepotrzebnym ciężarem, niemożliwym do udźwignięcia w danych okolicznościach. W prawie polskim wielokrotnie już dochodziło do tego rodzaju nadzwyczajnych sytuacji,

\section{Wykładnia norm prawnych odnosi się zawsze} do rzeczywistości zarówno przestrzennej, czasowej, jak i społecznej, w której jest dokonywana.

Przepisy o formie czynności prawnych odgrywają w obrocie istotną rolę stabilizującą. Określają one przesłanki, od których spełnienia będzie uzależniona ważność i pełna skuteczność czynności prawnej - stanowiąc w tym zakresie wyraźny komunikat dla stron, w jaki sposób powinny złożyć swoje oświadczenia. $\mathrm{Z}$ tych przyczyn przepisy normujące formy szczególne - co odnosi się także do czynności prawnych dokonywanych z udziałem notariusza - należy odczytywać w możliwie stabilny sposób, możliwie blisko ich dosłownego (językowego) brzmienia ${ }^{29}$.

27 Niedochowanie wymogu zachowania formy szczególnej innej niż zwykła forma pisemna, forma dokumentowa lub kwalifikowana forma elektroniczna powoduje sankcję nieważności bezwzględnej (art. $73 \$ 1$ k.c.). - por. M. Gutowski, Nieważność czynności prawnej, wyd. 4, Warszawa 2017, s. 196 , 197; P. Skorupa, Nieważność czynności prawnej w prawie polskim na tle prawnoporównawczym, Warszawa 2019, s. 574.

28 Warto zauważyć, iż na podstawie art. 15 ustawy z dnia 2 marca 2020 r. o szczególnych rozwiązaniach związanych z zapobieganiem, przeciwdziałaniem i zwalczaniem COVI-19, innych chorób zakaźnych oraz wywołanych nimi sytuacji kryzysowych (Dz.U. z 2020 r. poz. 374 z późn. zm.) posiedzenia organów osób prawnych mogą się odbywać z wykorzystaniem komunikacji elektronicznej bez konieczności jednoczesnej obecności członków tych organów.

29

Por. M. Grochowski, Wymogi formalne w umowach konsumenckich, Warszawa 2018, s. 71-74; M. Matczak, Summa także w odniesieniu do wymogów formy aktu notarialnego i innych czynności notarialnych. Prowadziło to albo do reinterpretacji wymogów formalnych w taki sposób, by zapewnić im większą elastyczność, albo do całkowitego pomijania skutków naruszenia tego wymogu (i traktowania czynności prawnej tak, jak gdyby została dokonana skutecznie) ${ }^{30}$.

Sytuacja tego typu zaistniała w warunkach pandemii COVID-19, która postawiła przed obrotem notarialnym bardzo poważne utrudnienia (zważywszy na dotąd stosowaną praktykę w zakresie usług notarialnych). Sytuacja ta jednak nie stanowi przesłanki proponowanej tu wykładni. Tradycyjna wykładnia przepisów ustawy z dnia 14 lutego 1991 r. - Prawo o notariacie, która wymaga fizycznej obecności wszystkich stron czynności notarialnej w tym samym miejscu i czasie, dodatkowo pogłębia skalę problemu w obecnej sytuacji zagrożenia epidemicznego. Wykładnia obecnie akceptowana w praktyce notarialnej nie jest jedyną możliwą do przyjęcia wykładnią przepisów o czynnościach notarialnych de lege lata. Także bowiem w aktu-

iniuria. O błędzie formalizmu w stosowaniu prawa, Warszawa 2007, s. 18; ogólnie o wykładni przepisów odnoszących się do formy oświadczeń woli także A. Jędrzejewska, Pisemna forma oświadczenia woli a „automatyzacja” obrotu prawnego, „Państwo i Prawo” 1993, nr 1, s. 69-74.

30 Por. szerzej M. Grochowski, Skutki braku..., s. 184-201. 
alnym stanie prawnym jest możliwe podejście, które pozwoli na zastosowanie obowiązujących przepisów do obecnych nadzwyczajnych okoliczności - przy jednoczesnym zachowaniu podstawowych funkcji form notarialnych. Dokonywane w ten sposób czynności będą mogły zostać uznane w konsekwencji za w pełni ważne i skuteczne, na równi z czynnościami dokonanymi w sposób tradycyjny. Co więcej, czynienie zadość formom czynności prawnych z udziałem notariusza przy użyciu nowych technologii obecnie - z uwagi na szczególne okoliczności - może być kontynuowane także po ich ustaniu. Okoliczności te dają jedynie asumpt do nowego spojrzenia na praktykę czynności notarialnych. W normalnych okolicznościach wypracowanie porozumienia i zgoda na akceptację nowych form praktyki notarialnej w omawianym zakresie zajęłyby zapewne wiele lat, a obecnie - rzec można stało się to koniecznością chwili. znacznych zmian legislacyjnych oraz organizacyjno-technologicznych - tak by dokumenty notarialne sporządzane w ramach komunikacji na odległość mogły być archiwizowane oraz by możliwe było sporządzanie wypisów. W pełni zasadne jest więc, by rozpocząć dyskusję nad koniecznymi zmianami, dla której punktem odniesienia mogłyby stać się dobrze funkcjonujące w praktyce i sprawdzone e-protokoły.

\section{Identyfikacja online osób dokonujących czynności notarialnych}

Jedną z przeszkód podnoszoną dotychczas przez środowisko notarialne w zakresie niedopuszczalności dokonywania czynności notarialnych online jest niemożność stwierdzenia tożsamości uczestnika czynności. W art. $85 \$ 1$ pr. not. na notariusza został nałożony obowiązek, aby przy dokonywaniu czynności notarialnej zweryfikował tożsamość jej uczestni-

\section{Analogicznie do e-protokołu - procedura dokonania czynności notarialnej może mieć w całości charakter zapisu audio-wideo.}

Mając na uwadze powyższe argumenty na rzecz wykorzystania nowych technologii przy sporządzaniu aktu notarialnego, można stwierdzić, że - analogicznie do e-protokołu ${ }^{31}$ - procedura dokonania czynności notarialnej może mieć w całości charakter zapisu audio-wideo. Rozwiązanie to wymagałoby jednak nie-

31 Wprowadzenie do polskiego systemu prawnego nowej techniki zapisu przebiegu posiedzeń i rozpraw sądowych nastąpiło na mocy ustawy z dnia 29 kwietnia 2010 r. o zmianie ustawy - Kodeks postępowania cywilnego (Dz.U. nr 108, poz. 684), która weszła w życie 1 lipca 2010 r., oraz rozporządzenia Ministra Sprawiedliwości z 10 sierpnia 2011 r. w sprawie zapisu dźwięku albo obrazu i dźwięku z przebiegu posiedzenia jawnego (Dz.U. nr 175, poz. 1046), które weszło w życie 1 października 2011 r.; zob. także ustawę z dnia 29 sierpnia 2014 r. o zmianie ustawy - Kodeks postępowania cywilnego oraz ustawy o kosztach sądowych w sprawach cywilnych (Dz.U. z 2014, poz. 1296). ków. Zgodnie z $\$ 2$ stwierdzenie tożsamości powinno nastąpić na podstawie prawem przewidzianych dokumentów, a wobec ich braku - w sposób wyłączający wszelką wątpliwość co do określenia tożsamości osoby biorącej udział w czynności notarialnej. Przesłanką prawidłowego wykonania przez notariusza obowiązku określonego $\mathrm{w}$ art. $85 \$ 1$ pr. not. jest stwierdzenie tożsamości osoby biorącej udział w czynności notarialnej poprzez wcześniejszą pozytywną weryfikację (ocenę) wiarygodności przedstawionego notariuszowi dokumentu tożsamości. Notariusz ocenia wówczas, czy ze względu na cechy zewnętrzne tego dokumentu i treść zawartych w nim wpisów nie zachodzi wątpliwość co do jego autentyczności bądź podejrzenie jego sfałszowania.

$Z$ reguły notariusz nie jest $\mathrm{w}$ stanie stwierdzić, czy okazany mu dokument tożsamości jest sfałszowany, jeżeli nie wykazuje oczywistych cech budzących wąt- 
pliwości (bez względu na to, czy ocena dokonuje się bezpośrednio, czy też odbywałaby się na odległość przy użyciu nowych technologii). W judykaturze przyjmuje się, że notariusz „ma obowiązek zachowania »maksimum przezorności« na każdym etapie dokonywanych z jego udziałem czynności (...). Intensywność oceny wiarygodności dokumentu tożsamości powinna być wzmożona, jeżeli zachodzą szczególne okoliczności dotyczące samego dokumentu albo zewnętrzne wobec niego - które powinny nasunąć starannie działającemu notariuszowi wątpliwości co do autentyczności cji wiarygodności i autentyczności co akt notarialny sporządzany tradycyjnie.

Dotychczas stwierdzenie tożsamości następowało w kancelarii notariusza poprzez fizyczne okazanie dowodu tożsamości. W czasie COVID-19 rozwiązanie takie jest jednak co najmniej ryzykowne pod względem epidemiologicznym (obecność wielu osób w kancelarii łączy się z fizycznym ich kontaktem) a w wielu wypadkach może być zwyczajnie sprzeczne z prawem (w związku z ograniczeniami w opuszczaniu domu i przemieszczaniu się). Nie oznacza

\section{Przy sporządzaniu aktu notarialnego na odległość} konieczne jest takie procedowanie, które zapewni ten sam poziom gwarancji wiarygodności i autentyczności co akt notarialny sporządzany tradycyjnie.

dokumentu lub tożsamości osób biorących udział w czynności" ${ }^{\prime 2}$. Nie ma przeszkód, aby postulat ten został zastosowany także do aktu notarialnego sporządzanego na odległość.

Artykuł 85 pr. not. stanowi bez wątpienia element systemu gwarancji wiarygodności i autentyczności oświadczeń, które zostały złożone lub utrwalone $\mathrm{z}$ udziałem notariusza. Tym samym należy on do gwarancji szczególnej pozycji wymogów formalnych o charakterze notarialnym, jako najwyższego szczebla w systemie wymogów formalnych w prawie prywatnym $^{33}$. W konsekwencji także przy sporządzaniu aktu notarialnego na odległość konieczne jest takie procedowanie, które zapewni ten sam poziom gwaran-

32 Tak w tezie wyroku SN z dnia 14 czerwca 2017 r., IV CSK 104/17, OSNC 2018, nr 3; por. także: tezę wyroku SN z dnia 26 lipca 2012 r., II CSK 750/11, Legalis nr 544301; postanowienie WSA w Gliwicach z dnia 12 lutego 2007 r., I SA/Gl 1512/06, Legalis nr 109406.

33 Por. np. A. Oleszko, Komentarz do art. 79 (w:) A. Oleszko, Prawo o notariacie. Komentarz, cz. II, t. 2, Warszawa 2012, teza 8. to jednak, by tradycyjna praktyka weryfikowania tożsamości była jedynym możliwym rozwiązaniem. Potwierdzenie tożsamości osób, które biorą udział w czynności notarialnej, jest możliwe także w sposób, który wykluczałby konieczność fizycznego kontaktu stron ${ }^{34}$.

Rozwiązaniem tego problemu może być prowadzenie przez notariusza komunikacji z uczestnikami czynności notarialnej poprzez wideokonferencję online, która w całości byłaby nagrywana, a weryfikacja tożsamości następowałaby w trzech etapach.

Po pierwsze, uczestnik czynności okazywałby dowód tożsamości online (do kamery), później zaś notariusz porównywałby zdjęcie w dokumencie z twarzą osoby biorącej udział w czynności ${ }^{35}$ (tak jak ma to miejsce obecnie w ramach tradycyjnej procedury sporządzenia aktu notarialnego).

34 Por. także M. Lorenc, Elektroniczna forma notarialna..., s. 21 i n.

35 Taki sposób weryfikacji dopuszczalny jest m.in. w prawie bankowym. Wideoweryfikacja jest jednym z elementów spełnienia przesłanek formy szczególnej z art. 7 pr. bank. 
Po drugie, system informatyczny dokonywałby równocześnie technicznego potwierdzenia autentyczności dowodu tożsamości oraz weryfikował dane biometryczne, zestawiając ze sobą zdjęcie i skan twarzy weryfikowanej osoby. System taki używany jest obecnie przez niektóre banki czy przy weryfikacji dowodów tożsamości na przejściach granicznych, co znacznie ułatwiałoby stworzenie podobnego narzędzia na użytek notariuszy.

Po trzecie, etapy te byłyby poprzedzone weryfikacją przy aktywowaniu kwalifikowanego podpisu elektronicznego dokonywaną przez podmiot zaufany (wydający kwalifikowany podpis elektroniczny) na podstawie rozporządzenia eIDAS ${ }^{36}$ i polityki certyfikacji ${ }^{37}$. Następuje ona poprzez fizyczną weryfikację osoby z dokumentem przedstawionym przez tę osobę (w sposób identyczny jak przy fizycznej obecności dokonuje tego notariusz w przyjętej obecnie praktyce notarialnej) $)^{38}$.

Taki sposób weryfikacji tożsamości jest wystarczający do spełnienia przesłanek z art. 85 pr. not. Podobna metoda weryfikacji jest przy tym dopuszczalna już de lege lata w postępowaniu cywilnym, w ramach przesłuchań na odległość (art. $235 \$ 23$ k.p.c.) oraz postępowania odmiejscowionego (art. $151 \S 2$ k.p.c.), a także w e-rozprawach. Nie jest to zatem rozwiązanie nowe ani nieznane w polskim systemie prawnym ${ }^{39}$,

36 Rozporządzenie Parlamentu Europejskiego i Rady (UE) nr 910/2014 z dnia 23 września 2014 r. w sprawie identyfikacji elektronicznej i usług zaufania w odniesieniu do transakcji elektronicznych na rynku wewnętrznym oraz uchylające dyrektywę 1999/93/WE (Dz.Urz. UE L 257 z 28.08.2014, s. 73-114).

37 Szerzej na temat eIDAS, podpisów elektronicznych zob. D. Szostek (w:) Informatyzacja..., s. 91-100; tenże (w:) Informatyzacja postępowania cywilnego. Teoria i praktyka, red. K. Flaga-Gieruszyńska, J. Gołaczyński, D. Szostek, Warszawa 2016, s. 3 i n.

38 Por. także J. Przetocki, Wykorzystanie środków... Szerzej na temat aspektów prawnych i technicznych potwierdzania tożsamości online E. Rott-Pietrzyk, D. Szostek, A new approach to the legal understanding of "directness" and "participation" in the aftermath of COVID-19 (w:) Corona and the Law, ed. E. Hondius, M. Santos Silva, P. Salvador Coderch, A. Nicolussi, F. Zoll (przyjęte do druku).

39 Dnia 21 kwietnia 2020 r. po raz pierwszy w Polsce przeprowadzono pełne posiedzenie sądowe całkowicie online, łącząc a jego ulokowanie w systemie prawa nie nastręcza poważniejszych trudności ${ }^{40}$.

Interpretując regulację odnoszącą się do weryfikacji tożsamości, należałoby przyjąć, że spełnia ona wymogi zdania pierwszego art. $85 \$ 2$ pr. not. (weryfikacja dowodu tożsamości przez oprogramowanie). Ewentualnie należałoby zastosować rozwiązanie określone w art. $85 \$ 2$ in fine pr. not., tj. uznać, że brak fizycznego przedstawienia dokumentu tożsamości jest traktowany jako brak dokumentu, jednak mimo jego braku tożsamość może zostać potwierdzona m.in. poprzez nagranie obrazu i dźwięku uczestnika oraz zdalną weryfikację dowodu (o ile nastąpi to w sposób wyłączający wszelką wątpliwość co do określenia tożsamości osoby biorącej udział w czynności notarialnej) ${ }^{41}$.

Należy przy tym zaznaczyć, iż samo nagranie zawierające dokonywanie czynności notarialnej, w tym procesu identyfikacji, jest dokumentem w znaczeniu prawa polskiego. Zgodnie bowiem z art. $77^{3}$ k.c. ${ }^{42}$

się z pełnomocnikami będącymi w swoich kancelariach. Całość została nagrana na e-protokół.

40 Ustawą o szczególnych rozwiązaniach związanych z zapobieganiem, przeciwdziałaniem i zwalczaniem COVID-19, innych chorób zakaźnych oraz wywołanych nimi sytuacji kryzysowych (Dz.U. z 2020 poz. 374), artykułem 15 zzs (1) wprowadzono zmianę w procedurze cywilnej, zgodnie z którą rozprawę lub posiedzenie jawne przeprowadza się przy użyciu urządzeń technicznych umożliwiających przeprowadzenie ich na odległość $\mathrm{z}$ jednoczesnym bezpośrednim przekazem obrazu i dźwięku, z tym że osoby w nich uczestniczące nie muszą przebywać w budynku sądu, chyba że przeprowadzenie rozprawy lub posiedzenia jawnego bez użycia powyższych urządzeń nie wywoła nadmiernego zagrożenia dla zdrowia osób w nim uczestniczących. Jeżeli ze względu na szczególne okoliczności prezes sądu tak zarządzi, członkowie składu, z wyjątkiem przewodniczącego i referenta sprawy, mogą brać udział w posiedzeniu za pomocą środków komunikacji elektronicznej. Na posiedzeniu, na którym dochodzi do zamknięcia rozprawy, musi być obecny sąd w pełnym składzie.

41 Por. art. $85 \$ 2$ in fine pr. not., zgodnie z którym: „w braku takich dokumentów - w sposób wyłączający wszelką wątpliwość co do określenia tożsamości osoby biorącej udział w czynności notarialnej”.

42 Przepis ten został wprowadzony ustawą z dnia 10 lipca 2015 r. o zmianie ustawy - Kodeks cywilny, ustawy - Kodeks 
dokumentem jest nośnik informacji umożliwiający zapoznanie się z jej treścią ${ }^{43}$, w tym zapis, obraz lub dźwię $\mathrm{k}^{44}$. W analogiczny sposób kwestię tę określa art. 3 pkt 35 rozporządzenia eIDAS, zgodnie z którym dokument elektroniczny oznacza każdą treść przechowywaną w postaci elektronicznej, w szczególności tekst lub nagranie dźwiękowe, wizualne lub audiowizualne ${ }^{45}$. $\mathrm{W}$ konsekwencji samo nagranie z przebiegu dokonania interpretacji obowiązujących przepisów odnoszących się do sporządzania aktu notarialnego nie odbiega zatem od praktyki stosowanej w wymiarze sprawiedliwości. Nie ma zatem przeszkód natury praktycznej w zastosowaniu tych rozwiązań do czynności notarialnych, w szczególności aktu notarialnego. Samo utrwalenie praktyki dokonywania czynności notarialnych w tradycyjnej postaci nie jest jeszcze dosta-

\section{Dokumenty notarialne mogą być opatrywane} tzw. kwalifikowanym podpisem elektronicznym, który wywołuje skutek prawny równoważny z podpisem własnoręcznym.

czynności notarialnej staje się dokumentem - a tym samym dostarcza dowodu na prawidłowe dokonanie weryfikacji tożsamości w rozumieniu art. 308 k.p.c.

Taki sposób pojmowania dokumentu i dowodu nie stanowi więc novum dla prawa polskiego (notabene podobne znaczenie mają także nagrania sporządzane w ramach tzw. e-protokołu ${ }^{46}$ ). Proponowana zmiana

postępowania cywilnego oraz niektórych innych ustaw (Dz.U. z 2015 r., poz. 1311 z późn. zm.), która weszła w życie 8 września $2016 \mathrm{r}$.

43 Bliżej na ten temat T. Tomczak, Pojęcie formy dokumentowej i dokumentu na gruncie Kodeksu cywilnego oraz forma dokumentowa przy następczych czynnościach prawnych, „Monitor Prawniczy” 2017, nr 6, s. 314-322, 314 i n.; P. Konik, M. Pannert, Materialnoprawne i procesowe aspekty formy dokumentowej i dokumentu, „Edukacja Prawnicza” 2018, nr 2, s. 36-41.

44 Por. szerzej M. Grochowski, Nowe koncepcje regulacji wymogów formalnych w prawie polskim, „Kwartalnik Prawa Prywatnego" 2017, t. 26, nr 4, s. 837.

45 Szerzej D. Szostek (w:) Informatyzacja...., s. 69 i n.

46 Por. S. Kotecka, „Protokół elektroniczny” w świetle rozporządzenia w sprawie zapisu dźwięku albo obrazu i dźwięku z przebiegu posiedzenia jawnego, „Prawo Mediów Elektronicznych” 2011, nr 3, s. 22 i n.; J. Gołaczyński, E-protokót wyzwaniem dla wymiaru sprawiedliwości, „Prawo Mediów tecznym argumentem, by uznać, że nowe technologie gromadzenia i transmisji danych - szeroko wykorzystywane w sądownictwie - nie mogłyby trafić także do obrotu notarialnego.

\section{Podpis na akcie notarialnym}

Zgodnie $\mathrm{z}$ art. $88 \$ 1$ pr. not. podpisy na aktach notarialnych i poświadczonych dokumentach składane są w obecności notariusza. Nie oznacza to jednak, by obecność ta musiała mieć charakter fizyczny, a więc by notariusz i uczestnik (uczestnicy) czynności musieli znajdować się w tym samym miejscu. W świetle rozporządzenia eIDAS dokumenty notarialne mogą być opatrywane tzw. kwalifikowanym podpisem elektronicznym, który zgodnie z art. 25 ust. 2 rozporządzenia wywołuje skutek prawny równoważny z podpisem własnoręcznym ${ }^{47}$. Na podstawie tej regulacji w każ-

Elektronicznych” 2012, nr 1, s. 13 i n.; D. Szostek, Quo vadis, czyli informatyzacja postępowania cywilnego w Polsce, rozdz. IV (w:) Aktualne problemy egzekucji sądowej w Polsce i na Litwie. Zbiór studiów, red. A. Marciniak, V. Nekrošius, Sopot 2017, pkt 5.

47 Por. A. Zaccaria (w:) EU eIDAS. Regulation, red. tenże i in., Beck-Hart-Nomos 2020, s. 9 i n.; D. Szostek (w:) Informatyzacja...., s. $96 \mathrm{i} \mathrm{n.}$ 
dym przypadku, gdy przepisy prawa krajowego wymagają podpisu własnoręcznego, zarówno dla czynności materialnoprawnych, jaki i proceduralnych (czy też faktycznych), istnieje możliwość zastąpienia go kwalifikowanym podpisem elektronicznym. Należy dodać, że państwa członkowskie mają możliwość wyłączenia tego przepisu w przypadku niektórych czynności. Polska nie skorzystała z takiej możliwości. W konsekwencji należy przyjąć, iż dopuszcza równoważność (zastępowalność) podpisu własnoręcznego i elektronicznego we wszystkich sytuacjach. niem elektronicznym, które służy do uwierzytelniania kwalifikowanego podpisu elektronicznego ${ }^{49}$. Po drugie, na notariuszu spoczywa obowiązek obserwacji procesu podpisywania sporządzonego w ten sposób aktu notarialnego. Nie ma przeszkód, aby następnie w razie wątpliwości - porównać nagranie (na którym wyświetlany byłby czas - godzina) oraz czas złożenia podpisu na dokumencie. Oba powinny być tożsame. Złożenie kwalifikowanego podpisu elektronicznego zawsze powiązane jest $\mathrm{z}$ zapisem czasu jego dokonania. Większość polskich kwalifikowanych podpi-

\section{Należałoby się zastanowić, czy argumentacja} dotycząca ekwiwalentności czynności notarialnych online z czynnościami inter praesentes nie powinna mieć zastosowania przede wszystkim w odniesieniu do profesjonalnych uczestników obrotu.

Akt notarialny w postaci elektronicznej może zostać podpisany w różny sposób: przez przesłanie mailem pliku, który następnie zostaje opatrzony kwalifikowanym podpisem elektronicznym, albo poprzez umieszczenie dokumentu w chmurze i podpisanie go elektronicznie przez uczestników aktu notarialnego. W celu uczynienia zadość przesłankom art. 88 $\$ 1$ pr. not. proces podpisywania elektronicznie przez uczestnika powinien być obserwowany przez notariusza w ramach wideokonferencji. Notariusz powinien obserwować, po pierwsze, sposób aktywowania kwalifikowanego podpisu elektronicznego za pomocą tokena OTP, czyli generatora hasła jednorazowego (ang. one-time password - OTP) ${ }^{48}$, będącego urządze-

48 Zob. Polski Komitet Normalizacyjny, Technika informatyczna. Zabezpieczenia w systemach informatycznych. Terminologia, PN-I-02000, marzec 2002, s. 47. OTP jest to hasło jednorazowe, zmieniane po każdym użyciu, stosowane w celu autoryzacji dostępu w systemach teleinformatycznych. Hasła te pozwalają ograniczyć zagrożenie podsłuchania lub sów elektronicznych jest automatycznie powiązanych z kwalifikowanym elektronicznym znacznikiem czasu, a co za tym idzie, zgodnie $z$ art. $81 \S 2$ pkt 3 k.c., sporządzony w ten sposób dokument spełnia - od daty opatrzenia kwalifikowanym znacznikiem - wymogi daty pewnej ${ }^{50}$.

podejrzenia hasła przez osoby niepowołane i posługiwania się nim bez wiedzy podmiotu uprawnionego. Hasło jednorazowe jest wykorzystywane tylko raz i traci ważność po wykorzystaniu.

49 Według art. 3 rozporządzenia eIDAS urządzenie do składania podpisu elektronicznego oznacza skonfigurowane oprogramowanie lub skonfigurowany sprzęt, które wykorzystuje się do składania podpisu elektronicznego (kwalifikowane urządzenie to urządzenie do składania podpisu elektronicznego, które dodatkowo spełnia wymagania określone w załączniku 2. rozporządzenia eIDAS); bliżej zob. D. Szostek (w:) Informatyzacja..., s. 91-100.

50 J. Grykiel (w:) Kodeks cywilny, t. 1, Komentarz do art. 1-352, red. M. Gutowski, Warszawa 2016, s. 560-565. 


\section{Problem osób szczególnie wymagających ochrony}

Analizując ekwiwalencję aktu sporządzanego przy zastosowaniu technologii pozwalającej na odpowiednio bezpieczną komunikację online, należy rozważyć, czy $\mathrm{w}$ istocie zawsze zostanie zapewniona realizacja tych samych funkcji, jakie zapewnia czynność notarialna dokonywana przy fizycznej obecności jej uczestników (tj. w sposób tradycyjny). Obawy powstają w szczególności w stosunkach prawnych o charakterze czysto prywatnym. Istnieje bowiem zagrożenie, że w sytuacji sporządzania aktu na odległość notariusz nie będzie w stanie ocenić, czy dana osoba nie jest poddana wpływom osób będących w miejscu, w którym osoba składająca oświadczenie woli w formie aktu notarialnego się znajduje. Ostatecznie w przypadku posługiwania w odniesieniu do profesjonalnych uczestników obrotu, w przypadku których wystąpienie sygnalizowanych wyżej zagrożeń i ograniczeń jest znacząco mniejsze. W każdym razie ustawodawca, regulując w przyszłości problematykę aktów notarialnych online, powinien rozważyć ich zakres podmiotowy - tak, aby przyjęte rozwiązania były użyteczne dla uczestników obrotu, którzy mieliby z nich korzystać.

\section{Elektroniczny wypis aktu notarialnego}

Warto zaznaczyć, że w prawie polskim już de lege lata występują rozwiązania częściowo zbliżone do proponowanej koncepcji czynności notarialnych dokonywanych na odległość. Nowelizacja ustawy - Prawo o notariacie wprowadziła w 2018 r. nowy art. $110 a^{51}$, zgodnie z którym dopuszczalny jest elektroniczny

\section{Zmiany o charakterze technicznym musiałyby} dotyczyć organizacji pracy oraz zapewnienia odpowiednio zabezpieczonego systemu informatycznego, pozwalającego na zdalną transmisję dokonywanych czynności notarialnych, nagranie ich oraz obieg elektroniczny dokumentów.

się podpisem elektronicznym nie jest możliwe, a przynajmniej jest bardzo utrudnione zweryfikowanie, czy to właśnie osoba wykazana tym podpisem przeprowadziła autonomicznie procedurę jego składania. W tego rodzaju stosunkach osoby fizyczne dość rzadko także posługują się technologią podpisu elektronicznego. Procedura otrzymania własnego podpisu elektronicznego nie jest łatwiejsza od sporządzenia aktu notarialnego i także wymaga w typowych sytuacjach fizycznego kontaktu z inną osobą. W tym kontekście należałoby się zatem zastanowić, czy przedstawiona tu argumentacja dotycząca ekwiwalentności czynności notarialnych online z czynnościami inter praesentes nie powinna mieć zastosowania przede wszystkim wypis aktu notarialnego. W myśl $₫ 1$ tego artykułu w nagłówku elektronicznego wypisu aktu notarialnego zaznacza się, że wydany dokument jest wypisem. Elektroniczny wypis aktu notarialnego jest dosłownym powtórzeniem oryginału, jednak poprawek i przekreśleń znajdujących się w oryginale nie zamieszcza się w wypisie. Elektroniczny wypis aktu notarialnego notariusz opatruje kwalifikowanym podpisem elektronicznym i umieszcza w repozytorium.

Istotne z perspektywy omawianej koncepcji aktów notarialnych sporządzanych na odległość jest także

51 Artykuł 110a pr. not. dodany ustawą z dnia 26 stycznia $2018 \mathrm{r}$. (Dz.U. z 2018 r. poz. 398), która weszła w życie 9 kwietnia 2018 r. 
rozwiązanie przewidziane w art. $97 \$ 2$ pr. not., wedle którego elektroniczne poświadczenie zgodności odpisu, wyciągu lub kopii z okazanym dokumentem notariusz opatruje kwalifikowanym podpisem elektronicznym. Poświadczenie notarialne opiera się tu na podobnym założeniu, które towarzyszy sporządzaniu samego aktu notarialnego przy wykorzystaniu nowych technologii. Różnica sprowadza się do tego, że jako jedyny kwalifikowany podpis elektroniczny składa w przypadku elektronicznego poświadczenia notariusz ${ }^{52}$.

\section{Konkluzje}

Zdaniem autorów tego opracowania niewielkie zmiany legislacyjne pozwolą na zmianę praktyki przy sporządzaniu aktów notarialnych i dokonywaniu innych czynności notarialnych polegającej na wykorzy- organizacyjnej i technicznej mogą w krótkim czasie sprawić, że polski notariat będzie w stanie wykorzystywać narzędzia elektroniczne pozwalające na dokonywanie czynności notarialnych - a przynajmniej niektórych z nich - na odległość. Konieczne jest utworzenie lub pozyskanie odpowiedniego systemu informatycznego oraz zmiany przepisów wykonawczych dotyczących przechowywania dokumentów i ich archiwizowania (w tym zakresie wzorem mogą być rozwiązania stosowane już w administracji i wymiarze sprawiedliwości).

Na przyjęcie tego rozwiązania pozwalają de lege lata omawiane wyżej przepisy prawa. Po pierwsze, gwarantują one zachowanie wszystkich funkcji aktu notarialnego. Po drugie, zapewniają bezpieczeństwo obrotu przy właściwym wykorzystaniu dostępnych narzędzi gromadzenia i przekazywania danych, opar-

\section{Pandemia COVID-19 ujawniła, jak konieczne jest} kompleksowe zinformatyzowanie polskiego notariatu.

staniu nowych technologii. Zmiany prawa o notariacie o charakterze kosmetycznym (o których mowa niżej w odniesieniu do art. 92a pr. not.) oraz zmiany natury

52 W podobny sposób kwestię tę reguluje także w prawie niemieckim \$39a ustawy o aktach notarialnych Beurkundungsgesetz (BGBl. I 1969 S. 1513), który dopuszcza możliwość sporządzania elektronicznych poświadczeń notarialnych. Wymagają one opatrzenia treści oświadczenia kwalifikowanym podpisem elektronicznym. Ponadto do sporządzonego w ten sposób dokumentu musi zostać dołączone potwierdzenie statusu notariusza. Jednocześnie notariusz ma także możliwość poświadczania dokumentów elektronicznych. W takim przypadku jest on zobowiązany do stwierdzenia autentyczności podpisu elektronicznego (i poświadczenia wyniku tej weryfikacji). Koncepcja ta opiera się na dwóch poziomach ekwiwalentności między tradycyjnymi i elektronicznymi elementami dokumentu notarialnego. Z jednej strony własnoręczny podpis notariusza jest tu zastępowany przez podpis elektroniczny - z drugiej strony w miejsce pieczęci notariusza (jako poświadczenia jego upoważnienia do wykonywania tej funkcji urzędowej) ustawa wymaga elektronicznego dokumentu potwierdzającego jego status. tych na nowoczesnych technologiach informatycznych. Zmiany o charakterze technicznym musiałyby dotyczyć natomiast organizacji pracy oraz zapewnienia odpowiednio zabezpieczonego (zgodnie z wymogami cyberbezpieczeństwa i zachowania tajemnicy notarialnej) systemu informatycznego, pozwalającego na zdalną transmisję dokonywanych czynności notarialnych, nagranie ich oraz obieg elektroniczny dokumentów.

Sytuacja związana z COVID-19 wymusza nowe, elastyczne spojrzenie na praktykę notarialną, która gwarantowałaby dostęp do notariatu w stanach kryzysowych. Natomiast niezależnie od takich stanów proponowana interpretacja i zmiany legislacyjne z pewnością sytuowałyby polski notariat w szeregu notariatów nowoczesnych, podążających za zmianami technologicznymi. Aktualne ograniczenia w poruszaniu i gromadzeniu się obywateli, przy tradycyjnym sposobie działania notariatu, w praktyce znacznie utrudniają dostęp do czynności notarialnych, lub wręcz go uniemożliwiają - bez stworzenia realnego zagrożenia dla zdrowia i życia lub naruszenia przepisów o izolacji społecznej. Już obecnie - w związku z COVID-19 - można 
zaobserwować zawieszenie działania wielu kancelarii notarialnych, a w każdym razie ograniczenie czasu i zakresu świadczonych przez nie usług. W krótkim horyzoncie czasowym brak bądź ograniczenie dostępu do notariatu byłyby możliwe do zaakceptowania. Jednak w dłuższej perspektywie (a wiele wskazuje na to, iż obecna sytuacja epidemiologiczna utrzyma się przez dłuższy czas lub może się powtórzyć) taki stan rzeczy wymaga dość szybkiej reakcji. Ograniczenie bądź w ogóle brak dostępu do notariatu są nie tylko szkodliwe dla obrotu gospodarczego, ale przede wszystkim dla życia społecznego, rodząc zagrożenie zdrowia i życia. nie w czasie epidemii czy w sytuacjach nadzwyczajnych. Jesteśmy przekonani, że obecne okoliczności szczególnie silnie ujawniły istniejącą już wcześniej potrzebę uelastycznienia i unowocześnienia praktyki dokonywania czynności notarialnych. W przyszłości w ogóle należałoby rozważyć kompleksową, systemową modernizację polskich przepisów o dokonywaniu czynności notarialnych. Proponowane na tym etapie zmiany stwarzają szanse znacznego ułatwienia praktyki notarialnej, także po normalizacji realiów życia gospodarczego i społecznego w Polsce, zaburzonego epidemią COVID-19. Pozwolą one na stworzenie dodatkowej

\section{Zmiana sposobu zawarcia aktu notarialnego} z tradycyjnego na elektroniczny spowodowałaby, że z biegiem czasu musiałaby się zmienić cała aktualna formuła działania notariatu.

Uprzedzając ewentualne wątpliwości co do dopuszczalności posługiwania się oświadczeniami elektronicznymi przy czynnościach urzędowych - do których należą czynności notarialne - można zauważyć, że już obecnie niektóre sądy, jak np. Sąd Okręgowy w Warszawie, dopuszczają wnoszenie pism procesowych w postaci elektronicznej ${ }^{53}$ (co przed czasami pandemii wydawało się niemożliwe). Uważamy, że analogiczne rozwiązania mogą zostać przyjęte także w praktyce notarialnej. Należy skorzystać z dostępnych regulacji prawnych i narzędzi technicznych, aby umożliwić nowoczesny, powszechny dostęp do notariatu. W nadzwyczajnych okolicznościach - jak COVID-19 umożliwi to dokonywanie czynności notarialnych (w szczególności sporządzanie aktów notarialnych) bez stwarzania zagrożenia epidemiologicznego.

Trzeba jednak podkreślić, że zarysowane wyżej propozycje nie powinny znajdować zastosowania wyłącz-

53 Zob. https://bip.warszawa.so.gov.pl/. Por. także S. Cydzik, Nie możemy pozwolić sobie na ponowne zawieszenie pracy sądów. Pora na rozprawy online, „Dziennik Gazeta Prawna”, 26.04.2020. możliwości usprawnienia i przyspieszenia dokonywania czynności notarialnych. Jest to szczególnie doniosłe w czasie szybkiego upowszechniania się komunikacji elektronicznej, która coraz częściej staje się podstawą wymiany informacji w wielu obszarach obrotu.

Na tym tle należy także zwrócić uwagę na pilną potrzebę zmiany art. 92a pr. not., który dotyczy Centralnego Repozytorium Elektronicznych Wypisów Aktów Notarialnych. W chwili obecnej możliwe jest zamieszczanie w nim elektronicznych wypisów określonych $w$ art. $92 \mathrm{a} \$ 2$ pr. not. (inne wypisy są w nim zamieszczane tylko o ile stanowi tak przepis szczególny). Należy zatem - dla spójności i funkcjonalności całego systemu - zmodyfikować ten przepis tak, by wszystkie elektroniczne wypisy aktów notarialnych podlegały wpisowi do rejestru. Można także w niedalekiej przyszłości rozważyć reorganizację repozytorium, tak aby - wykorzystując technologię blockchain ${ }^{54}$

54 Bliżej zob. D. Szostek, Blockchain and Law, Baden Baden 2019, s. 7 i n.; S. Nakamoto, Bitcoin: A Peer-to-Peer Electronic Cash System, 2008 r., https://bitcoin.org/bitcoin.pdf (dostęp 05.04.2020). s. 1-9. 
i tokenizację $e^{55}$ pojedynczych wypisów - możliwa była weryfikacja poszczególnych egzemplarzy wypisu. Rozwiązanie to nie nastręcza współcześnie poważniejszych problemów technicznych.

Pandemia COVID-19 ujawniła, jak konieczne jest kompleksowe zinformatyzowanie polskiego notariatu. Polska administracja i sądownictwo - gdzie proces informatyzacji gromadzenia i przekazu danych jest już bardziej zaawansowany - pomimo trudności organizacyjnych mogły w bardziej elastyczny sposób zareagować na społeczne i prawne skutki kryzysu.

Należy także dodać, że zmiana sposobu zawarcia aktu notarialnego z tradycyjnego na elektroniczny spowodowałaby, że z biegiem czasu musiałaby się zmienić cała aktualna formuła działania notariatu. Proponowany sposób interpretacji i proponowane zmiany legislacyjne nie polegają bowiem jedynie na tym, że podpis własnoręczny zmienia się na podpis elektroniczny, a sam akt notarialny jest dokonywany na odległość. Pojawiają się dalsze pytania. Po pierwsze, jak zmiana sposobu dokonywania czynności notarialnej wpłynie na całą instytucję notariatu i instytucje z notariatem powiązane (w szczególności sądy). Po drugie, jak należy postępować $z$ danymi w postaci elektronicznej oraz jaki podmiot miałby je przechowywać, mieć do nich dostęp i uprawnienia do ich przetwarzania (w szczególności czy tą instytucją miałby być notariat, czy inny podmiot). Pytania te wymagają odpowiedzi. Pierwszym krokiem musi być jednak przełamanie bariery, jaką stwarza tradycyjna interpretacja przepisów o dokony-

55 Bliżej zob. E. Ducas, A. Wilner, The security ona financial implications of blockchain technologies: Regulating emerging technologies in Canada, „International Journal” 2017, vol. 72, nr 4, s. 544; S. Haber, W.S. Stornetta, How to time-stamp a digital document, „Journal of Cryptology” 1991, nr 3, s. 99 i n.; R. Anderson, Security Engineering. A guide to Building Dependable Distributed System, New York 2008, s. 5 i n., zob. https://www.iacr.org/books/2010_ws_Anderson_SecurityEngineering.pdf (dostęp 02.04.2020) oraz wydanie wcześniejsze: Security Engineering. A guide to Building Dependable Distributed System, New York 2001, s. 6 i n.; Distributed Ledger Technology: beyond block chain. A report by the UK Government Chief Scientific Adviser, http://fintechpoland.com/wp-content/uploads/2017/01/ Technologie-rozproszonych-rejestrow-UK-GOfS-FTP-NASK-PL-1.pdf (dostęp 23.03.2020). waniu czynności notarialnych. Następnie musiałyby zostać podjęte działania na dwóch płaszczyznach: interpretacyjnej (zmiana metodologii wykładni przepisów obowiązujących), a także - w zidentyfikowanym w tym opracowaniu zakresie - legislacyjnej.

\section{Bibliografia}

Anderson R., Security Engineering. A guide to Building Dependable Distributed System, New York 2001 i 2008.

Bydlinski F., Juristische Methodenlehre und Rechtsbegriff, Wien 1991.

Cydzik S., Nie możemy pozwolić sobie na ponowne zawieszenie pracy sąów. Pora na rozprawy online, „Dziennik Gazeta Prawna” z 26.04.2020, https://prawo.gazetaprawna.pl/ artykuly/1472206,zawieszenie-pracy-sadow-rozprawy-online-wywiad.html (dostęp 16.06.2020).

Distributed Ledger Technology: beyond block chain. A report by the UK Government Chief Scientific Adviser, https://assets. publishing.service.gov.uk/government/uploads/system/uploads/attachment_data/file/492972/gs-16-1-distributed-ledger-technology.pdf (dostęp 21.06.2020).

Drozd E., Z problematyki zawarcia umowy $w$ formie aktu notarialnego, „Rejent” 1996, nr 4-5, s. 11-24.

Drozd E., Kuniewicz Z. (w:) Prawo cywilne - część ogólna, red. Z. Radwański, A. Olejniczak, „System Prawa Prywatnego”, t. 2, wyd. 3, Warszawa 2019, s. 173-244.

COVID-19 pandemic. Impact of COVID-19 on Court Operations $\$$ Litigation Practice, ed. J. Galway, U. Hoffmann-Nowotny, International Bar Associattion, https://www.lalive.law/wp -content/uploads/2020/05/2020-SGI-IBA_Impact_of_COVID19_on_court_operations_and_litigation_practice.pdf (dostęp 16.06. 2020).

Ducas E., Wilner A., The security ona financial implications of blockchain technologies: Regulating emerging technologies in Canada, „International Journal” 2017, vol. 72, nr 4, s. 538-562. Gołaczyński J., E-protokół wyzwaniem dla wymiaru sprawiedliwości, „Prawo Mediów Elektronicznych” 2012, nr 1, s. 13-17.

Górecki J., Forma umów obligacyjnych i rzeczowych w prawie prywatnym międzynarodowym, Katowice 2007.

Górska K., Zachowanie zwykłej formy pisemnej czynności prawnych, Warszawa 2007.

Grochowski M., Nowe koncepcje regulacji wymogów formalnych w prawie polskim, „Kwartalnik Prawa Prywatnego” 2017, t. 26 nr 4, s. 805-843.

Grochowski M., Skutki braku zachowania formy szczególnej, Warszawa 2017. 
Grochowski M., Wymogi formalne w umowach konsumenckich, Warszawa 2018.

Grykiel J. (w:) Kodeks cywilny, t. 1, Komentarz do art. 1-352, red. M. Gutowski, Warszawa 2016, s. 560-565.

Gutowski M., Nieważność czynności prawnej, Warszawa 2017. Haber S., Stornetta W.S., How to time-stamp a digital document, "Journal of Cryptology” 1991, nr 3, s. 99-111.

Jędrzejewska A., Pisemna forma oświadczenia woli a „automatyzacja” obrotu prawnego, „Państwo i Prawo” 1993, nr 1, s. 69-74.

Klich A. (w:) Informatyzacja postępowania cywilnego. Komentarz, red. J. Gołaczyński, D. Szostek, Warszawa 2016, s. 179-189.

Konik P., Pannert M., Materialnoprawne i procesowe aspekty formy dokumentowej i dokumentu, „Edukacja Prawnicza” 2018, nr 2, s. 36-41.

Kotecka S., „Protokół elektroniczny” w świetle rozporzadzenia w sprawie zapisu dźwięku albo obrazu i dźwięku z przebiegu posiedzenia jawnego, „Prawo Mediów Elektronicznych” 2011, nr 3, s. 22-27.

Lorenc M., Elektroniczna forma notarialna, rozwiązania przyjęte w prawie europejskim - model francuski, „Nowy Przegląd Notarialny" 2008, nr 1, s. 16-24.

Łazarska A., Komentarz (w:) Kodeks postępowania cywilnego, t. 1, Komentarz do art. $1-505^{39}$, red. T. Szanciło, Warszawa 2019, s. 591-592.

Mankowski P., Formzwecke, „JuristenZeitung” 2010, nr 13, s. $662-668$.

Markiewicz R., Komentarz do art. 151 (w:) Kodeks postępowania cywilnego, t. 1, Komentarz do art. $1-505^{39}$, red. T. Szanciło, Warszawa 2019, s. 907-908.

Matczak M., Summa iniuria. O błędzie formalizmu w stosowaniu prawa, Warszawa 2007.

Mikulska D., Czy w obecnej sytuacji możliwe jest doprowadzenie do sprzedaży nieruchomości? (25.03.2020), https://www.nieruchomosci-online.pl/porady/epidemia-koronawirusa-czy-mozliwa-jest-sprzedaz-nieruchomosci-11545.html (dostęp 29.04.2020).

Nakamoto S., Bitcoin: A Peer-to-Peer Electronic Cash System, 2008 r., https://bitcoin.org/bitcoin.pdf (dostęp 05.04.2020). s. 1-9.

Oleszko A., Akty notarialne. Komentarz (art. 91-95 Prawa o notariacie), Warszawa 2012.

Oleszko A., Komentarz do art. 79 (w:) A. Oleszko, Prawo o notariacie. Komentarz, cz. II, t. 2, Warszawa 2012, s. 23-204.

Osajda K., Prawo spadkowe (w) przyszłości. Perspektywy rozwoju prawa spadkowego, „Monitor Prawniczy” 2019, nr 2, s. 66-75.
Polski Komitet Normalizacyjny, Technika informatyczna. Zabezpieczenia $w$ systemach informatycznych. Terminologia, PN-I02000, marzec 2002.

Przetocki J. , Wykorzystanie środków przekazu elektronicznego, między innymi e-podpisu w praktyce notarialnej, „Rejent” 2006, nr 5, s. 165-180.

Rojek-Socha P., Ojczyk J., Kancelarie notarialne zamykają się $z$ powodu koronawirusa (28.04.2020), https://www.prawo. $\mathrm{pl} /$ prawnicy-sady/kancelarie-notarialne-zamykaja-sie-z-powodu-koronawirusa-dane,499846.html (dostęp 29.04.2020). Rojek-Socha P., Ojczyk J., Koronawirus zatapia notariuszy, kołem ratunkowym - akty online (3.04.2020), https://www.prawo.pl/ prawnicy-sady/elektroniczny-akt-notarialny-rekomendacje-jak-wprowadzic-w,499237.html (dostęp 29.04.2020).

Rott-Pietrzyk E., Szostek D., A new approach to the legal understanding of "directness" and "participation" in the aftermath of COVID-19 (w:) Corona and the Law, ed. E. Hondius, M. Santos Silva, P. Salvador Coderch, A. Nicolussi, F. Zoll (przyjęte do druku).

Rüthers B., Die Unbegrenzte Auslegung, Tübingen 2012.

Rymanowska-Mrugała K., Akt notarialny jako szczególna forma dokumentu urzędowego, „Folia Iuridica Universitatis Wratislaviensis" 2016, t. 5, nr 1, s. 219-238.

Skorupa P., Nieważność czynności prawnej w prawie polskim na tle prawnoporównawczym, Warszawa 2019.

Szostek D., Blockchain and Law, Baden Baden 2019.

Szostek D., Quo vadis, czyli informatyzacja postępowania cywilnego w Polsce, rozdz. IV (w:) Aktualne problemy egzekucji sądowej w Polsce i na Litwie. Zbiór studiów, red. A. Marciniak, V. Nekrošius, Sopot 2017, s 91-97.

Szostek D. (w:) Informatyzacja postępowania cywilnego. Komentarz, red. J. Gołaczyński, D. Szostek, Warszawa 2016, s. 45-110. Szostek D. (w:) Informatyzacja postępowania cywilnego. Teoria i praktyka, red. K. Flaga-Gieruszyńska, J. Gołaczyński, D. Szostek, Warszawa 2016, s. 61-71,

Tomczak T., Pojęcie formy dokumentowej i dokumentu na gruncie Kodeksu cywilnego oraz forma dokumentowa przy następczych czynnościach prawnych, „Monitor Prawniczy” 2017, nr 6, s. 314-322.

Wasińska E., Sytuacja notariuszy w obliczu zagrożenia epidemia koronawirusa (z 17.03.2020), https://www.lex.pl/sytuacja-prawna-notariuszy-w-obliczu-zagrozenia-epidemia-koronawirusa,6181 (dostęp 29.04.2020).

Zaccaria A. (w:) EU eIDAS. Regulation, red. tenże i in., 2020, s. 3-142. 